\title{
An Economic Analysis of the Fiscal Policy FRAMEWORK IN THE EMU
}

\author{
Kirill Albrecht
}

\begin{abstract}
This paper intends to provide an economic analysis of the European Monetary Union (EMU). The focus will be on examining the present fiscal policy framework in the EMU. It will be argued that the enforcement of the current framework is weak and has led to excessive deficits in the Eurozone. Measures to strengthen the framework and restore fiscal discipline and sustainable debt levels in the Eurozone will be analysed. It is submitted that the enforcement of the present fiscal framework and fiscal discipline can be strengthened through Eurobonds that are issued jointly by all members of the Eurozone. In order to provide for an effective issuance mechanism a limited form of coordination would be needed that would require minor amendments to existing institutions.
\end{abstract}

\section{A. INTRODUCTION}

This paper intends to provide an economic analysis of the European Monetary Union (EMU). The focus will be on examining the present fiscal policy framework in the EMU. It will be argued that the enforcement of the current framework is weak and has led to excessive deficits in the Eurozone. Measures to strengthen the framework and restore fiscal discipline and sustainable debt levels in the Eurozone will be analysed. It is submitted that the enforcement of the present fiscal framework and fiscal discipline can be strengthened through Eurobonds that are issued jointly by all members of the Eurozone. In order to provide for an effective issuance mechanism a limited form of coordination would be needed that would require minor amendments to existing institutions. The paper will be structured into seven parts. Part B will offer a summary of the theoretical foundations of the EMU while Part $\mathrm{C}$ will provide a description of the current enforcement mechanism of fiscal discipline, the Stability and Growth Pact (SGP). Part D will give a summary of the recent problems in the Eurozone. The most prominent suggestions to reform the SGP will be analysed in Part E. Part F will discuss the creation of a system of fiscal federalism in the EMU. The potential problems arising from such a system will also be discussed. The advantages and disadvantages of introducing Eurobonds will be summarised in Part G. This section will also feature an analysis of specific proposals on how to 
implement Eurobonds. Part $\mathrm{H}$ will offer a proposal of how a Eurobonds system could be effectively integrated in the current EMU framework. Finally, the conclusion will offer a summary of the findings.

\section{B. The Theoretical Foundation of the EMU}

The EMU is founded upon the model of Optimum Currency Areas pioneered by Mundell, which is based on the traditional Keynesian assumption of fixed prices and wages. A country taking part in a monetary union, which is hit by an exogenous shock, can no longer rely on its own monetary and exchange rate policy to counteract such a shock. ${ }^{1}$ Thus, in the logic of the optimum currency area theory, entering a monetary union entails the loss of one important tool of national macroeconomics stabilisation policy, namely monetary policy. Given the loss of monetary policy, one would expect that a fiscal system in the form of a common budget would act as a buffer against shocks. Despite structural funds to ensure convergence between rich and poor regions, the overall Community budget is very modest. ${ }^{2}$ Due to its small size, the budget cannot fulfil any significant role for macroeconomic stabilisation and no additional insurance scheme was put into place. ${ }^{3}$ Moreover, the welfare state in all EMU members was created before they entered the EMU. The distributive function is therefore assigned at national level. ${ }^{4}$ The EMU framework reinforces this division by stipulating that the basic responsibility for fiscal policy remains at the national level. Consequently, the Union budget does not carry out any stabilising function. ${ }^{5}$ Fiscal policy in the EMU is therefore highly decentralised, while monetary policy is unified under the auspices of the European Central Bank (ECB). National policy makers rely on fiscal policy rather than on the Community budget to provide macroeconomic stabilisation against asymmetric shocks. ${ }^{6}$ Within this decentralised framework, unilateral decisions to lower or to increase tax rates may create

\footnotetext{
${ }^{1}$ Hedwig Ongena and Bernhard Winkler, 'Fiscal Policy in EMU' in Michael Artis and Frederick Nixson (eds), The Economics of the European Union (OUP 2001), 315. 2 Guido Montani, 'The Role of the European Budget in European Economic Policy' (2005) 3 The Federalist 136, 142.

${ }^{3}$ Ongena and Winkler (n 1) 322.

${ }^{4}$ Montani (n 2) 141.

${ }^{5}$ ibid 142.

${ }^{6}$ Paul De Grauwe, Economics of Monetary Union (OUP 2009), 224.
} 
asymmetric shocks. The fact that social security and wage policies are also decided at the national level is a further breeding ground for asymmetric shocks. This can be illustrated by the case of France when it decided alone to lower the working week to 35 hours, which had an impact on the other members of the EMU. In a similar manner, Germany has been applying tough wage moderation since 1999, thereby significantly improving its competitive position at the expense of other members of the EMU. ${ }^{7}$

The structural design of EMU, featuring a single monetary policy while vesting responsibility for fiscal policy at the national level, has also led to a supply-side fragmentation of the national bond markets. ${ }^{8}$ The sovereign debt of each country in the Eurozone is issued under the control of the respective Ministries of Finance. ${ }^{9}$ Thus, at the moment, the market is fragmented across 17 individual countries with different credit ratings and issuance calendars. In this framework, liquidity is generally concentrated among the larger EMU members such as Germany and France. Therefore, smaller issuers have to compete with more liquid and near-substitute bonds, which negatively affects the liquidity of their own bonds. As a result, the overall euro-denominated government bond market suffers from a lack of liquidity. ${ }^{10}$ Within this market, many countries have resorted to substituting default for currency risk in order to relieve monetary pressure.

\section{The Current Fiscal Framework in the EMU}

Article 126 of the Treaty on the Functioning of the European Union and the Protocol on the excessive deficit procedure provide the framework for fiscal policies in the EMU. The Treaty set outs quantitative targets on the size of government deficits and public debt, where 'member states shall avoid excessive government deficits'. ${ }^{11}$ Compliance with fiscal discipline

\footnotetext{
${ }^{7}$ Paul De Grauwe, 'Some Thoughts on Monetary and Political Union' in Leila Simona Talani (ed), The future of EMU (Palgrave Macmillan 2009), 14.

${ }^{8}$ Werner Becker, 'The creation of a common European government bond. Arguments against and alternatives' (2010) 14 Cahier Comte Boel 25, 30.

${ }^{9}$ Maria Lorca-Susino, The Euro in the 21st Century: Economic Crisis and Financial Uproar (Ashgate, 2011), 143.

${ }^{10}$ John Berrigan, 'Joint issuance of euro-denominated government bonds' (2010) 14 Cahier Comte Boel 20.

${ }^{11}$ Treaty of Lisbon amending the Treaty on European Union and the Treaty establishing the European Community [2007] OJ C306/01.
} 
is judged on the basis of two criteria, namely the "ratio of the planned or actual government deficit to gross domestic product' and the 'ratio of government debt to gross domestic product'. ${ }^{12}$ They must not exceed certain reference values, which were set at $3 \%$ and $60 \%$ respectively. ${ }^{13}$ The Stability and Growth Pact (SGP) was designed to enforce this framework by coordinating national fiscal policies to ensure long-term sustainability of public finances.

The Pact comprises both a preventive and dissuasive arm. The preventive arm serves as an early warning system. Each EMU member submits an annual stability programme, which includes its budgetary position and the economic policy measures to achieve its budgetary targets. The Commission will analyse each proposal and issue a proposal to the Council. In case of concern, the latter can then issue an early warning to prevent an excessive deficit. The Commission can also give recommendations to a state concerning the consequences of its fiscal policies. ${ }^{14}$ The dissuasive arm of the SGP takes effect if a state breaches the $3 \%$ ceiling. This will trigger an excessive deficit procedure, where the Council issues a recommendation to the respective state on how to remedy the deficit identified. If the state does not comply with the recommendation within a given time frame, it may be subject to financial sanctions. ${ }^{15}$ Following some criticism, the SGP was amended in March 2005. The amendments were designed to make the interpretations of the deficit ceilings more flexible, which included adjustments for cyclical conditions. This evolution of the SGP stretched the limits of the Pact to a maximum level of flexibility, without rendering it impotent. ${ }^{16}$

\footnotetext{
12 ibid.

${ }^{13}$ Protocol (No 12) on the excessive deficit procedure [2007] OJ C115/279.

${ }^{14}$ Council Regulation (EC) 1466/97 of 7 July 1997 on the strengthening of the surveillance of budgetary positions and the surveillance and coordination of economic policies [1997] OJ L209/1.

${ }^{15}$ Council Regulation (EC) $1467 / 97$ of 7 July 1997 on speeding up and clarifying the implementation of the excessive deficit procedure [1997] OJ L209/6.

${ }^{16}$ Antonio Fatas and IIian Mihov, 'The Euro and Fiscal Policy' in Alberto Alesina and Francesco Giavazzi (eds), Europe and the Euro (University of Chicago Press 2010), 294.
} 


\section{The Eurozone Crisis}

To counteract the loss of authority over monetary policy, many EMU members were abusing fiscal policy. This abuse was exacerbated after the global financial crisis and the subsequent recession, which saw a need for fiscal stimulus plans and bank bailouts. In order to implement these measures, governments resorted to a drastic increase in spending, financed by issuing more sovereign debt. ${ }^{17}$ As a result, many countries in the Eurozone now have excessive deficits, far exceeding the 3\% and $60 \%$ limits set out by the Treaty. A further problem is the significant increase of the sovereign yield spreads within the Eurozone. In the EU, yield differentials are measured by the spread between the German yield and national sovereign bond yields. ${ }^{18}$ Before the crisis, there were slight but not significant yield differentials between the German Bund and the yields of other countries. ${ }^{19}$ However, after the financial crisis investors have been pursuing a policy of 'flight to quality', buying governments bonds considered as safe from triple-A-rated countries like Germany. ${ }^{20}$ This has resulted in a sharp widening of sovereign debt spreads since EMU members with a lower credit rating were faced with a much larger interest rates on their debt. In February and March 2009, the interest rate differential with respect to German debt was 100 basis points for Italy, Portugal and Spain while Greece and Ireland faced an even higher difference of 250 basis points. ${ }^{21}$ The unsustainable deficits of some countries in the Eurozone have led to a loss of credibility among investors, ultimately resulting in rating agencies downgrading the sovereign debt rating of Greece. ${ }^{22}$ As a consequence, Greece had to pay a higher credit risk premium on its sovereign debt. This had clear spill-over effects as the increase in the Greek premium influenced the Italian interest rate spread, which rose above the US BAA-AAA corporate spread to reach nearly 200 basis points. ${ }^{23}$ Thus, the spread differentials

\footnotetext{
${ }^{17}$ Lorca-Susino (n 9) 144.

${ }^{18}$ ibid 153 .

${ }^{19}$ ibid 143.

${ }^{20}$ Becker (n 8) 27.

${ }^{21}$ Wim Kösters, 'Common Euro Bonds - No Appropriate Instrument' (2009) 44 Intereconomics 135.

${ }^{22}$ Lorca-Susino (n 9) 148.

${ }^{23}$ Carlo Favero and Alessandro Missale 'EU Public Debt Management and Eurobonds' in European Parliament's Committee on Economic and Monetary Affairs
} 
within the Eurozone widened further as members with weaker ratings, who were already facing higher interest rates, saw credit risk premiums rise even further. These developments cast doubt on whether some states, Greece in particular, would be able to service their sovereign debt considering their excessive current account deficit. Consequently, the fear of government default became a tangible risk, as evidenced by the increase in the demand for credit default swaps (CDSs). ${ }^{24}$ Moreover, cross-border holdings of national bonds and the interlinked European banking system have served as a channel for crisis transmission. ${ }^{25}$ Thus, many banks holding Greek sovereign debt were facing the possibility of sitting on illiquid assets. ${ }^{26}$

In response to these developments, a rescue package of $€ 750$ billion was created, comprising a $€ 250$ billion contribution from the IMF and two new schemes. The European Financial Stabilisation Mechanism (EFSM) has a relatively small lending capacity of $€ 60$ billion while the European Financial Stability Facility (EFSF) may provide loans of up to $€ 440$ billion. $€ 110$ billion were subsequently allocated to Greece. ${ }^{27}$ However, the scheme was rather ineffective as Greece was still faced with high interest rate of $5 \%$ on its sovereign debt. Thus, it was not able to cut its debt level to sustainable levels but instead faced an even higher debt burden. ${ }^{28}$ Consequently, a second bailout package for Greece in the amount of $€ 109$ billion was agreed in 2011. The conditions of this package were changed, resulting in longer periods of maturity and lower interest rates on Greek debt. These favourable conditions were also extended to Ireland and Portugal. ${ }^{29}$ It was further decided that the temporary EFSF would be replaced by a permanent European Stabilisation Mechanism (ESM) in 2012. Both the EFSF and the ESM will have a flexible credit line and their overall flexibility has been

(ed), Euro Area Governance - Ideas for Crisis Management Reforms (European Parliament 2010) 102.

${ }^{24}$ Lorca-Susino (n 9) 143.

${ }^{25}$ Favero and Missale (n 23) 102.

${ }^{26}$ Lorca-Susino (n 9) 186.

${ }^{27}$ Wim Kösters, 'Credible Rules, Not Discretion, Will Make the Euro Sustainable' (2010) 45 Intereconomics 340.

${ }^{28}$ Ansgar Belke and Christian Dreger, 'Ramifications of Debt Restructuring on the Euro Area' (2011) 46 Intereconomics 188.

${ }^{29}$ ibid 189. 
increased. They can also act in a pro-active manner to stabilise the markets, using their resources to recapitalise banks and intervene in secondary markets. ${ }^{30}$

Greece continued to struggle with unsustainable debt levels, and therefore the second bailout package was increased to $€ 130$ billion in February 2012. Moreover, a debt restructuring scheme was attached to the package, which aimed to reduce Greece's debt burden through private sector involvement (PSI). Greece made a tender offer to holders of Greek law bonds under which they were to agree to a 53.5 per cent cut of the nominal value of their bonds. 86 per cent of bondholders agreed to the exchange and in order to increase the participation rate, Greece activated collective action clauses (CACs) that allow the terms of bonds to be modified if a certain percentage of bondholders agrees. However, the activation of CACs resulted in the ISDA declaring this a "credit event" ${ }^{\text {, }}$ which triggered payouts of $€ 3$ billion on Greek CDSs. The transaction allowed Greece to cut $€ 100$ billion from its overall $€ 350$ billion debt. ${ }^{32}$

In March 2012, 25 members of the EU, except for the United Kingdom and the Czech Republic, signed a Fiscal Compact, which requires the signatories to implement a provision into their domestic legal system, which ensures that the government budget is balanced or in surplus. ${ }^{33}$ Moreover, the Eurogroup, comprising the finance ministers of the Eurozone, agreed to temporarily combine the lending capacities of the ESM and the EFSF until the ESM is fully capitalised. Under this scheme the EFSF will continue to service the $€ 200$ billion in loans it has already granted to Greece, Ireland and Portugal. Since the maximum lending capacity of the ESM has been set at $€ 500$ billion, the combined lending ceiling of the ESM and the EFSF will now be $€ 700$ billion. Combined with $€ 49$ billion from the EFSM and $€ 53$ billion out of previous bilateral

\footnotetext{
${ }^{30}$ Waltraud Schelkle, 'The Euro Area After Another Crisis Summit: Ignore the Elephant in the Room at Your Peril' (2011) 46 Intereconomics 178.

${ }^{31}$ EMEA Determinations Committee 'Statement' (9 March 2012)

$<$ http://www.isda.org/dc/docs/EMEA_Determinations_Committee_Statement_09032 012.pdf $>$ accessed on 18 March 2012.

${ }^{32}$ David Oakley, Joshua Chaffin and Richard Milne, 'Greek debt swap triggers massive payouts' Financial Times (9 March 2012) $<$ http://www.ft.com/intl/cms/s/0/7e3855ce-69ba-11e1-a26e00144feabdc0.html\#axzzlusOp10Vy> accessed on 18 March 2012.

33 Treaty on Stability, Coordination and Governance in the Economic and Monetary Union 2012.
} 
loans from the first Greek rescue package an overall firewall of roughly $€ 800$ billion has been put in place. ${ }^{34}$

One can conclude that the current enforcement of the EMU's fiscal framework is weak, which manifests itself at the unsustainable debt levels of many EMU members. Considering the excessive deficits in the Eurozone, the SGP has clearly failed in enforcing fiscal discipline and ensuring sustainable fiscal policies. Neither the preventive arm nor the dissuasive arm of the excessive deficit procedure provided sufficient incentives for countries to consolidate their public finances. ${ }^{35}$ The measures and bailout packages that have been recently implemented present short-term solutions, which do not sufficiently strengthen the existing fiscal framework. A permanent stabilisation mechanism is a step forward but it is a rather superficial tool that will only intervene when the risk of fiscal hazard is about to materialise. It does not provide long-term incentives to countries for following the established deficit ceiling. The recently bolstered firewall is less impressive upon closer examination. Taking away the debt already committed, 'only' $€ 500$ billion are left, which would certainly not be sufficient if larger Eurozone members such as Spain or Italy could not service their debts anymore. The fiscal compact, on the other hand, tackles the problem at its core by pushing down deficits. However, this focus on austerity comes at the expense of economic growth thereby curtailing economic recovery and rendering a return to sustainable debt levels more difficult. A new system should ideally provide both short-term flexibility that will allow fiscal policy to act as a counter-cyclical instrument and a credible commitment to sound public finances and long-term debt sustainability, while also providing room for economic growth and recovery. A logical conclusion is that the present weaknesses in the EMU fiscal framework can be attributed to the limitations of the SGP. Consequently, it is the SGP itself that needs to be reformed. Therefore, the following section will analyse proposals suggesting a reform of the Pact.

\footnotetext{
${ }^{34}$ Statement of the Eurogroup (30 March 2012)

$<\mathrm{http} / /$ www.consilium.europa.eu/uedocs/cms_data/docs/pressdata/en/ecofin/129381. pdf $>$ accessed on 6 April 2012.

${ }^{35}$ Peter Bofinger and Stefan Ried, 'A New Framework for Fiscal Policy

Consolidation in Europe' (2010) 45 Intereconomics 203, 204.
} 


\section{E. Suggested Reforms of The Stability ANd Growth PaCt}

\section{Extending the SGP to the National Level}

Reform policies on a regional level affect the aggregate performance of a monetary union. ${ }^{36}$ Thus, fiscal discipline could be strengthened by focusing on the quality of national fiscal institutions. The SGP would be complemented with a surveillance framework that encourages governments to adopt procedures conducive to sound public finances. However, this scheme poses problems in terms of the reliability of the monitoring scheme and its costs. Giving an accurate estimate of the Gross Domestic Product (GDP) would not be easy, if the bodies under surveillance are too small in economic terms. This would affect the meaningfulness of available data. Moreover, measuring local investment expenditure that is financed through local taxation would also be problematic. Large and costly projects would show up as expenditure peaks, distorting the data. Finally, the high number of bodies that have to be monitored could make this scheme very costly. ${ }^{37}$

\section{An Aggregate Deficit Criterion}

Under the current fiscal framework, each country is responsible for national fiscal policies. Thus, the aggregate fiscal stance is not taken into account, which may lead to a suboptimal fiscal stance at the EMU level. Therefore, the aggregate fiscal policy stance of the EMU should be subject to the regulations of the SGP. Instead of each individual member of the EMU, only the EMU as a whole would be subject to the $3 \%$ deficit criterion. ${ }^{38}$ However, if some members of the EMU had deficits below the deficit ceiling, other members could run excessive fiscal policies as long as the aggregate deficit of the EMU is below 3\%. This would provide a clear incentive for some states to free-ride on the stable budgets

\footnotetext{
${ }^{36}$ Kenneth Kletzer and Jürgen von Hagen, 'Monetary Union and Fiscal federalism' (2000) < http://www.uni-mannheim.de/edz/pdf/zei/b00-01.pdf $>$ accessed on 18 August 2012, 29.

${ }^{37}$ Fabrizio Balassone and Daniele Franco, 'Fiscal Federalism and the Stability and Growth Pact: A Difficult Union' in Marco Buti and Daniele Franco (eds), Fiscal Policy in Economic and Monetary Union: Theory, Evidence and Institutions (Edward Elgar Publishing Ltd 2005), 158.

${ }^{38}$ Marco Buti, Sylvester Eijffinger and Daniele Franco, 'Revisiting EMU's Stability Pact: A Pragmatic Way Forward' (2003) 19 Oxford Review of Economic Policy 100, 103.
} 
of other, thus exacerbating the risk of moral hazard. A change of the budgetary rules to provide for an aggregate deficit criterion would therefore not be advisable.

\section{The Golden Rule}

Blanchard and Giavazzi assert that the SGP is flawed in terms of the way countries have to account for public investment. On this basis, they have proposed a Golden Rule. When assessing a country's budget, current expenditure in the form of nominal interest payments and capital depreciation should be distinguished from net investment. The latter should then be excluded from the deficit ceiling. ${ }^{39}$ However, the fact that deficit financing under this scheme is allowed may lead to opportunistic behaviour where proponents of a particular investment project may simply inflate the estimates of future revenues. Moreover, not including tax reforms that generate future revenues or investment in human capital in budget calculations is not based on any sound theoretical foundation. ${ }^{40}$ Excluding investment expenditure from the disciplinary framework of the SGP altogether may also culminate in undesirable levels of fiscal laxity, effectively giving a carte blanche on investment spending.

\section{The Permanent Balance Rule}

Buiter and Grafe envisage a Permanent Balance Rule that identifies a tax rate that can provide a country's solvency while maintaining sustainable levels of public debt. ${ }^{41}$ This tax rate would be based on the principle that future surpluses must not be exceeded by government debt. The rule considers inflation rates and GDP growth as well as future sources of revenues affected by public investment. By taking into account all these factors, in can enhance a government's flexibility in terms of allowing discretion from permanent fiscal levels. ${ }^{42}$ However, the practical

\footnotetext{
${ }^{39}$ Olivier Blanchard and Francesco Giavazzi, 'Improving the SGP through a proper accounting of public investment' (2004) CEPR Discussion Paper No. 4220 $<$ http://economics.mit.edu/files/735> accessed on 14 August 2012, 3.

${ }^{40}$ Lars Calmfors and Giancarlo Corsetti, 'How to Reform Europe's Fiscal Policy Framework' (2003) 4 World Economics 109, 116.

${ }^{41}$ Willem H. Buiter and Clemens Grafe, 'Patching up the Pact: Suggestions for enhancing fiscal sustainability and macroeconomic stability in an enlarged European Union' (2004) 12 Economics of Transition 67, 75.

42 ibid 77.
} 
application of this rule would involve complicated estimates of the permanent value of tax and spending. Thus, policy makers would have to make future predictions about growth rates as well as social and political preferences. Such a prediction would be prone to many errors and is therefore unlikely to yield sufficient results. ${ }^{43}$

\section{Exemptions from the Deficit Ceiling Based on an Index of Institutional Reform}

Eichengreen proposes that the SGP should focus on fiscal institutions rather than numbers. Consequently, countries with low public debts deficits should be exempted from the deficit ceiling. These exemptions would be based on an 'explicit index of institutional reform'. ${ }^{44}$ This index would be designed and implemented by an independent committee. Countries would receive points for structural reforms relating to their pension schemes, labour markets or unemployment insurance systems. If a country received three points, it would be exempted from the rules of the SGP. Eichengreen asserts this exemption would be justified since there would be no reason to 'expect that they will be prone to chronic deficits'. Institutions that do not receive the necessary index points would still be subject to the SGP's regulations and sanctions. ${ }^{45}$ This proposal certainly provides a powerful incentive for countries to implement structural reforms. However, this is not a long-term incentive. Once they are freed from the restraints of the SGP, there is no mechanism that prevents them from running new deficits.

\section{Fiscal Coordination through a Market-Based Allocation of National Deficit Shares}

Drawing an analogy to pollution permits, Casella proposes to introduce a system of tradable deficit permits where countries would be allowed to trade rights to deficit creation. The market would then allocate the permits at minimum costs and according to the financial needs of the respective countries. ${ }^{46}$ At the beginning of the year, countries would be

\footnotetext{
${ }^{43}$ Buti, Eijffinger and Franco (n 38) 106.

${ }^{44}$ Barry Eichengreen, 'Institutions for Fiscal Stability' (2004) 50 CESifo Economic Studies 1, 7.

${ }^{45}$ ibid.

${ }^{46}$ Alessandra Casella, 'Tradable Deficit Permits: Efficient Implementation of the Stability Pact in the European Monetary Union' (1999) 14 Economic Policy 321, 326.
} 
allocated a number of deficit permits that amount to $3 \%$ of their GDP and are freely tradable. In the next year, when fiscal statistics are made public, countries must prove that they possess a sufficient number of permits to cover their annual deficit. If a country is not able to cover its deficit, it will incur a fine for each missing permit. Moreover, it will face a cut in the number of permits allocated to it for the following year. ${ }^{47}$ The main advantage of such a system is that it would not affect the aggregate deficit of the EMU while allowing individual members to deviate from the initial allowances in order to respond to economic shocks. ${ }^{48}$ However, the difficulty with this system is that the deficits of each regional or local government are different and do no generate the same externality. Thus, substituting one deficit permit for another may be difficult since they would significantly differ in value. Determining an efficient system for the initial allotment of permits would also be quite problematic. Possible criteria such as the population of a member state would most likely result in widely differing allocations, which would again result in political tension. Moreover, the question of who would be in charge of such a system is left unaddressed. If governments themselves would be responsible, they could add exceptions or changes to the deficit ceiling, thereby undermining the system and fiscal stability. ${ }^{49}$

\section{An Economic Policy Charter}

Pisany-Ferry also suggests that the members of the EMU should adopt an economic policy charter that would serve as a code of conduct. ${ }^{50}$ This would cause some organisational problems. In order to ensure that national policy decisions do not contradict the common charter this would require that the interaction between charter and national budgetary procedures would have to be streamlined to a great extent. ${ }^{51}$ Moreover, the charter 'would not have a binding character' but would merely

\footnotetext{
${ }^{47}$ ibid 328.

48 ibid 329.

${ }^{49}$ Balassone and Franco (n 37) 160.

50 ibid 4.

${ }^{51}$ Carlo Panico and Marta Vazquez Suarez, 'Policy Coordination in the Euro Area' (2008) 96 Studi economici 5, 23.
} 
'represent a common understanding on economic policy principles'. 52 Thus, the whole intention of ensuring consistency between EMU and national policies would be somewhat undermined. ${ }^{53}$ This non-binding nature of the charter would in fact be a step-down from the current framework that, despite being ineffective, is still binding. A lack of binding constraints as suggested by this proposal would be a fertile breeding ground for free-riding and moral hazard.

\section{Fiscal policy committees}

Wyplosz believes that rules are too rigid and artificial to achieve both short and long-term objectives. Institutions create superior incentives to achieve these objectives. ${ }^{54}$ Wyplosz draws upon similarities between fiscal and monetary policy and proposes to use Monetary Policy Committees (MPCs) as points of reference for fiscal institutions. In central banking it is common practice to delegate monetary policy to MPCs that comprise an independent group of unelected experts. This committee is given a clear constitutional mandate by the political authorities to maintain price stability. ${ }^{55}$ The macroeconomic task of fiscal policy in terms of maintaining budgetary balance is not too different from monetary policy and can thus be delegated to an agent. On this basis, Wyplosz suggests setting up Fiscal Policy Committees (FPCs). The members of the latter would be unelected experts appointed for a fixed duration, which would guarantee their full independence. The FPC would be given a set debt target by the relevant political authorities. In order to ensure its accountability, the FCP would answer to a national elected body. ${ }^{56}$ However, since the FCPs are accountable to a national body, there is no incentive for governments to defer authority to them in terms of maintaining debt stability. Moreover, the fact there would be an FCP in every country would merely add an additional bureaucratic layer. Every FCP would be likely to implement measures that would rectify fiscal

\footnotetext{
${ }^{52}$ Jean Pisani-Ferry, 'Fiscal Discipline and Policy Coordination in the Eurozone: Assessment and Proposals' (2002) < http://www.pisani-ferry.net/base/re02-geadiscipline-vmai.pdf $>$ accessed on 8 August 2012, 4.

${ }^{53}$ Panico and Suarez (n 51) 23.

${ }^{54}$ Charles Wyplosz, 'Fiscal Discipline in EMU: Rules or Institutions?' (2002) Paper prepared for the Group of Economic Analysis of the European Commission, 4. 55 ibid 5.

${ }^{56}$ ibid 9.
} 
imbalances in their country of origin, and would not necessarily pay attention how these measures would affect the rest of the EMU. This would further exacerbate the problem of the EMU's decentralised fiscal framework.

A watered down version of Wyplosz's concept has been proposed by Eijffinger. ${ }^{57} \mathrm{He}$ envisages a Fiscal Experts Panel (FEP) that would give advice to the European Parliament on matters of fiscal policy. Like the FPCs suggested by Wyplosz the members of the panel would be independent experts that would be appointed for specified period. The FEP would be responsible for the current and future fiscal imbalances of the members of the EMU. They would then provide advice on how these imbalances could be rectified. ${ }^{58}$ This is a good proposal but it would need to be complemented with a system that provides strong incentives for countries to follow the recommendations of the FEP.

In summary, with the exception of Eijffinger's proposal, the suggested reforms of the SGP would not significantly strengthen the fiscal framework but lead to new problems instead. On this basis, the SGP should remain unchanged. The 2005 reform has already increased the flexibility of the Pact. Any further amendments would merely water it down unnecessarily, leaving it bereft of any significance. Thus, the SGP should remain a cornerstone of the EMU fiscal framework but the framework itself needs to be stabilised. One alternative would be transforming the EMU into a fiscal federal union, where a centralised stabilisation scheme would automatically stabilise fiscal imbalances.

\section{F. FisCAL FEDERALISM}

The perceived Achilles heel of the Euro is that represents a federal currency without a federal fiscal system. ${ }^{59}$ Common fiscal institutions can provide stabilisation across geographic regions and thus members of a

\footnotetext{
${ }^{57}$ Sylvester Eijffinger, 'Legislative proposals on EU economic governance' in A Makipaa (ed.) Legislative proposals on EU economic governance: what is missing within and beyond: Compilation of Briefing Papers (European Parliament 2010) $<$ http:/www.europarl.europa.eu/activities/committees/studies.do?language $=\mathrm{EN}>$ accessed on 4 August 2012, 37.

${ }^{58}$ ibid.

${ }^{59}$ Montani (n 2) 136.
} 
monetary union. ${ }^{60}$ In a monetary union, it may therefore be desirable to centralise part of the national budgets of member states to the federal level. Consequently, a European system of fiscal federalism could be created. This would entail a system of transfers among EMU members in the form of an expanded Community budget. In this scheme, contributions and expenditures would be linked to the economic situation of a country and act as a buffer during periods of cyclical divergence. ${ }^{61}$ Spill-over effects would thus be internalised. This central budget would act both as a redistributive device as well as a stabilising instrument. ${ }^{62}$ If regions experience asymmetric macroeconomic shocks, deficit-spending at the federal level would be used to stabilise weaker regions. ${ }^{63}$

In principle, a centralisation of national budgets would serve to accommodate for asymmetric shocks in the different member states of the EMU. Such a centralised budget would reduce the social costs of a monetary union by allowing countries and regions that are hit by negative shocks to enjoy automatic transfers. ${ }^{64}$ An EMU stabilisation scheme would provide insurance across regions through a system of fiscal transfers that would redistribute income from those regions which experience favourable economic developments relative to the EMU average to those which suffer from an adverse economic shock. ${ }^{65}$ Under such a system, a fall in income would result in declining tax payments, thereby absorbing the impact of the original shock. A rising unemployment rate would also induce increased transfers, which would cushion the subsequent loss of income. ${ }^{66}$ In theory, this would provide insurance through redistribution of income across different regions at any

\footnotetext{
${ }^{60}$ Erik Jones, 'European Fiscal Policy Co-ordination and the Persistent Myth of Stabilization' in Leila Simona Talani (ed), The future of EMU (Palgrave Macmillan 2009), 47.

${ }^{61}$ Barry Eichengreen, 'The Breakup of the Euro Area' in Alberto Alesina and Francesco Giavazzi (eds), Europe and the Euro (University of Chicago Press 2010), 41.

${ }^{62}$ De Grauwe, 'Some Thoughts on Monetary and Political Union' (n 7) 15.

${ }^{63}$ Michael Hutchison and Kenneth Kletzer, 'Fiscal Convergence Criteria, Factor Mobility, and Credibility in Transition to Monetary Union in Europe' in Barry Eichengreen, Jeffrey Frieden and Jürgen von Hagen (eds), Monetary and Fiscal Policy in an Integrated Europe (Springer-Verlag Berlin and Heidelberg $\mathrm{GmbH} \& \mathrm{Co}$ 1995), 150.

${ }^{64}$ De Grauwe, Economics of Monetary Union (n 6) 224.

${ }^{65}$ Ongena and Winkler (n 1) 316.

${ }^{66}$ Jones (n 60) 47.
} 
point in time. ${ }^{67}$ Hence, a system of fiscal federalism would replace regional fiscal policies for stabilising regional incomes in the face of differential aggregate supply and demand shocks. ${ }^{68}$

\section{Problems}

There are some inherent problems in creating an effective as well as neutral centralised stabilisation scheme. It is difficult to design a budgetary transfer mechanism in a way that avoids one of the classic problems of insurance literature, namely that of moral hazard. Under the latter, insurance affects the incentives of the insured to behave in a way that limits risky behaviour. Weaker countries may be tempted to profit from the compensation received through fiscal transfers rather than trying to reduce their vulnerability to economic shocks. ${ }^{69}$ Moreover, social security transfers reduce the need to adjust. They tend to keep real wages in the depressed regions too high, thereby reducing the incentive for the population of the respective region to move out to more prosperous regions. Consequently, interregional transfers have the potential to become self-perpetuating. Budgetary transfers should therefore only apply to temporary shocks and if a shock is permanent transfers should be used only on a temporary basis. ${ }^{70}$ However, from a practical point of view, it is not easy to separate temporary and permanent shocks and thus 'pure' insurance from the redistribution of wealth and income for other motives. ${ }^{71}$ Furthermore, empirical evidence suggests that it is difficult to use regional budgetary transfers in a temporary manner. The results shows that when a region experiences a negative shock such as the Mezzogiorno in Italy, or the eastern Länder in Germany, the transfers through the centralised social security system tend to acquire a permanent character. $^{72}$

The fact that for a stabilisation system to be effective, a continuous redistribution of resources through taxes and transfers is required presents an additional problem. Only a shock through income changes rather than through income levels would trigger a response from the stabilisation

\footnotetext{
${ }^{67}$ Ongena and Winkler (n 1) 316.

${ }^{68}$ Hutchison and Kletzer (n 63) 49.

${ }^{69}$ Ongena and Winkler (n 1) 317.

${ }^{70}$ De Grauwe, Economics of Monetary Union (n 6) 225.

${ }^{71}$ Ongena and Winkler (n 1) 317.

${ }^{72}$ De Grauwe, Economics of Monetary Union (n 6) 225.
} 
mechanism. If a country with high income suffered an exogenous shock, part of the income lost by its wealthiest citizens would be absorbed by declining tax outlays. In turn, transfer payments would replace part of the income lost by less wealthy citizens who face unemployment. However, the described effects could also have undesirable consequences. In case of a shock that only affects the wealthier members of the EMU, poorer countries would have to provide a cushion for the latter. Logically, they would be very reluctant to stabilise the income of the wealthier member states in response to exogenous shocks. ${ }^{73}$ In fact, it would represent a perversion of the scheme if at one point Greece or Ireland had to stabilise the income of Germany or France.

Large and potentially permanent regional transfers will result in new political problems. A jurisdiction that is diverse in terms of its political structure is less likely to offer insurance against shocks to all the citizens. ${ }^{74}$ When the sense of national identity is weak, this can effectively lead to a break-up of a country since the taxpayers of the more prosperous regions could simply reject payments to the poorer one. This risk can be illustrated by looking at the German system for Finanzausgleich between regional governments. During the German unification, integrating the eastern Länder proved to be difficult since the western Länder were reticent to make further payments to the East, as they were not considered proper members of the federation. Eventually, the German federal government was forced to absorb much of the costs. ${ }^{75}$ This is further exacerbated at the European level because the Eurozone comprises diverse national identities and the sense of national identification is much less developed than at the country level. ${ }^{76} \mathrm{~A}$ 'deep variable' or European identity would be necessary to maintain social and political cohesion but is absent at the European level. ${ }^{77}$ As a consequence, resistance to intercountry transfers may be considerable. This could result

\footnotetext{
${ }^{73}$ Jones (n 60) 49.

74 Alberto Alesina, Reza Baqir and William Easterly, 'Public Goods and Ethnic Divisions' (1999) 114 Quarterly Journal of Economics 1243, 1274.

${ }^{75}$ Jones (n 60) 48.

${ }^{76}$ Eichengreen (n 61) 42.

77 De Grauwe, 'Some Thoughts on Monetary and Political Union' (n 7) 26.
} 
in political problems, which would further endanger the unity of the Eurozone. $^{78}$

The other problem with a system of fiscal federalism would be that of democratic accountability. Under the present framework, national governments and parliaments are responsible for spending and taxation since democratic legitimacy is vested in these institutions. Any decision of a government to increase or decrease spending or taxation is judged by its national electorate. In contrast, the current control and sanctioning procedure imposed by the SPG is carried out by institutions that are perceived as lacking that very democratic legitimacy. ${ }^{79}$ Entirely replacing national fiscal policies with fiscal federalism would entail a further loss of autonomy, thereby exacerbating the inherent democratic deficit of the current framework. Keeping responsibility for fiscal policy at the national level may therefore be preferable for reasons of accountability. ${ }^{80}$

Moreover, in order to achieve effective transfers, either the Community budget would have to be significantly expanded or amendments to the current Treaty would have to be made. ${ }^{81}$ This would, however, raise the question of whether countries that are not part of the Eurozone would be willing to participate in these transfers. They made a conscious decision to not enter the Eurozone and would now be forced to stabilise a monetary union, which they specifically chose not to be a part of. The alternative would be creating a system of interstate transfers without the active involvement of the other EU members that would only include members of the Eurozone. ${ }^{82}$ Such a system would be likely to result in further fragmentation of the EU rather than facilitating political integration. Consequently, a significant transfer of budgetary power as well as a full centralisation of all areas of budgetary policy could be problematic. Thus, one should look to limited forms of centralisation. Rather than a fully centralised stabilisation scheme, a central debt instrument that would be cross-guaranteed by all the countries in the Eurozone may strengthen the fiscal framework. A common Eurobond is

\footnotetext{
${ }^{78}$ De Grauwe, Economics of Monetary Union (n 6) 225.

${ }^{79}$ De Grauwe, 'Some Thoughts on Monetary and Political Union' (n 7) 22.

${ }^{80}$ Ongena and Winkler (n 1) 317.

${ }^{81}$ Eichengreen (n 61) 41.

82 ibid 42 .
} 
an instrument that would satisfy this criterion and will be analysed in the following section.

\section{G. EUROBONDS}

\section{Advantages}

A common European government bond would promote further market integration as well as greater debt management coordination. The efficiency gains from a unified bond market would lead to enhanced liquidity. Greater liquidity would, in turn, reduce liquidity premia and the costs of borrowing for EMU members, with greater advantages for states with a lower credit rating. ${ }^{83}$ In order to illustrate this, one has to consider that the credit quality of a bond just guaranteed by France and Germany would be greater than the weighted average of the credit standings of other countries in the Eurozone. ${ }^{84}$ Such a common bond with higher liquidity would thus eliminate interest rate spreads across the Eurozone, resulting in cheaper budget financing. ${ }^{85}$ This would be particularly beneficial for countries that were severely affected by the financial crisis, in terms of easing their economic recovery. ${ }^{86}$

Most importantly, Eurobonds would provide insurance against credit risk and ensure continued market access to sovereign issuers who may have been shut out of the latter. As seen by the current situation, shocks originating in one country can have negative spill-over effects across the EMU, affecting credit risk premia and increasing the probability of crisis in other states. Consequently, a common debt backed by joint guarantees of all countries in the Eurozone or an EU Institution would reduce exposure to crisis transmission from contagion. Moreover, providing insurance to the country with the weakest fundamentals would work as an EMU-wide safety mechanism since it would also benefit all other states. ${ }^{87}$ Finally, since Eurobonds would be jointly guaranteed by several countries, the risk of default would be extremely low. This would make

\footnotetext{
${ }^{83}$ Favero and Missale (n 23) 101.

${ }^{84}$ ibid 102.

${ }^{85}$ Otmar Issing, 'Why a common eurozone bond isn't such a good idea' (2009) 12 Europe's World 76, 77.

${ }^{86}$ Becker (n 8) 27.

${ }^{87}$ Favero and Missale (n 23) 102.
} 
them extremely attractive for investors in large foreign-exchange reserves such as China, thereby enhancing the standing of the Euro as a reserve currency. ${ }^{88}$

\section{Disadvantages}

The most common argument against Eurobonds is that they undermine fiscal discipline by removing incentives for sound budgetary policies. The general political opposition derives from the fear that Eurobonds could create a moral hazard problem within the EMU. Thus, a country could free ride on the obligations of others who, in case of default, would be legally obliged to assume its debt and foot the bill. Countries with a strong credit rating such as Germany are particularly wary of this problem. In addition, due to the elimination of credit risk spreads financial markets could not perform their traditional function of acting as disciplinary restraints through higher interest rates. ${ }^{89}$ Thus, countries with low credit ratings could be tempted to neglect fiscal discipline and run excessive budget deficits since they would rely on being bailed out in any case. ${ }^{90}$ In a similar manner, states with sound budgets and low debts would be tempted to run lax fiscal policies and take up more debt. This would effectively undermine the credibility of the EMU. ${ }^{91}$

Another potential problem of a common sovereign bond is the equitable sharing of the benefits and costs of this debt instrument. The issue is particularly important as the success of Eurobonds depends on the willingness of countries in the Eurozone to use common bonds as funding instruments. ${ }^{92}$ States with both weak budgets and credit ratings have a clear incentive to quickly move to Eurobonds since they will make budget financing a lot cheaper. Moreover, all countries participating in the issuance of a Eurobond would benefit from greater liquidity. However, states with sound budgetary polices and low debts would potentially face higher credit risk premia and borrowing costs, while

\footnotetext{
${ }^{88}$ Sergio Mayordomo, Juan Ignacio Peña and Eduardo Schwartz, 'Towards a Common European Union Risk Free Rate' (2009)

$<$ http://papers.ssrn.com/sol3/papers.cfm?abstract_id=1569675 $>$ accessed 14 August $2012,2$.

${ }^{89}$ ibid 104.

${ }^{90}$ Becker (n 8) 29.

${ }^{91}$ Favero and Missale (n 23) 104.

92 ibid 103.
} 
effectively subsidising countries with weaker fiscal fundamentals. Hence, states with the high credit ratings would not necessarily have an incentive to join the scheme since they could face additional costs from the mutualisation of credit risk. ${ }^{93}$

The introduction of Eurobonds may also result in higher interest rates for existing national bonds. ${ }^{94}$ Eurobonds would connect fiscal responsibility and burden sharing within the EMU framework. Thus, countries with a triple-A rating would have to provide guarantees regarding interest payments and the redemption of the bonds for countries with lower ratings. However, if financial markets expect considerable amounts of new Eurobonds to be issued, interest rates on existing national bonds of countries with a high credit rating may rise significantly over time. This would adversely affect their interest payments in terms of financing not only their current budget deficits but also the refinancing of their maturing debt. Moreover, given their prospective high public borrowing requirements, this rise in interest rates may have a long-term negative impact on their credit rating. ${ }^{95}$ From a political point of view, countries with rising interest rates will face public discontent, since the additional financing will lead to higher tax burdens for their citizens. ${ }^{96}$ This could result in severe political repercussions, which would present a big hurdle to joint issuance. ${ }^{97}$ It would be seen as an inherent contradiction if countries with sound budgets and stable fiscal policies would have to pay a higher price to support countries with high deficits and weak public finances. Such a scenario would further undermine the stability status of the Eurozone, and thus the confidence of its citizens. ${ }^{98}$ Considering the absence of a European identity and the less than positive image of the Eurozone in many public opinion polls, a further increase in euro-scepticism would certainly not be desirable. ${ }^{99}$

Eurobonds would lead to increased liquidity and be very attractive for investors. This would trigger higher capital inflows and result in an increased exchange rate of the euro against the dollar. However, this

\footnotetext{
${ }^{93}$ ibid 106.

${ }^{94}$ Becker (n 8) 28.

95 ibid.

${ }^{96}$ Issing (n 85) 77-78.

${ }^{97}$ Berrigan (n 10) 24.

${ }^{98}$ Issing (n 85) 79.

${ }^{99}$ Becker (n 8) 29.
} 
perceived advantage could have severe repercussions. As seen by the period from 2007 to 2010 , with rates between 1.30 and 1.60 USD/EUR a strong euro could have a very negative impact on the price competitiveness of the export sector in the Eurozone. ${ }^{100}$ Another stumbling block would be the fact that Eurobonds are jointly guaranteed by all EMU members so they could, in principle, be liable for or assume the debt obligations of another government. However, this would violate the no-bailout clause and thus constitute a breach of Article 125 of the Lisbon Treaty. ${ }^{101}$ In light of these potential difficulties, the following sections will analyse concrete proposals for issuing Eurobonds.

\section{Eurobonds Based on EIB Equity Shares}

The hypothesis by De Grauwe and Moesen envisages a single debt instrument issued by a group of EMU members. In order to raise the necessary funds the respective obligations would be divided between participating countries in specifically fixed proportions. The interest rate on the common bond would be a weighed average of the yields observed in each national bond market at the time of issue. These weights would be calculated by reference to the individual equity shares of the participating countries in the European Investment Bank (EIB). The proceeds of the bond issue would then be distributed to the participants using the same weights. Finally, the yearly interest rate to be paid by each country on its part of the issue would be based on the national interest rates used to compute the average interest rate on the Eurobond. ${ }^{102}$ Consequently, each participating state would guarantee only its share of the instrument. While the Eurobond would trade as a single debt instrument, participants would not be liable for the debt of other issuers. Each country would be liable only for the interest payments and principal redemption that correspond to its share of the bond. The credit standing of such a common bond would be perceived as the average of the credit standings of the participating countries. Its liquidity, on the other hand, would certainly be greater than that of the national bonds of the participating countries. ${ }^{103}$

\footnotetext{
100 ibid 27.

${ }^{101}$ Kösters (n 21) 137.

102 Paul De Grauwe and Wim Moesen, 'Gains for all: A proposal for a common euro bond' (2009) 44 Intereconomics 132, 136.

103 ibid.
} 
The great advantage of this proposal is that it significantly reduces the risk of moral hard since countries pay the same rate as on their national government bonds. ${ }^{104}$ Thus, the incentive of countries with weaker credit rating to free ride on triple-A-rated countries would decrease. Moreover, the common argument against Eurobonds that states with a stronger credit rating may be penalised by higher interest rates would no longer apply. ${ }^{105}$ The other advantage of this proposal is the fact that participants are not jointly but merely severally liable to the extent of their contributions. This design does not bring the scheme in conflict with any legal provisions, namely the no-bailout clause. At the same time, the proposal guarantees access to the market for all participants, which would greatly benefit countries such as Greece.

One of the shortcomings of this proposal is its limited degree of flexibility. In order to enhance liquidity and facilitate the pricing of risk, subsequent bond issues would have to be comparable over time. This could, however, only be ensured by keeping both the set of participating countries and their shares in the common bond constant over time. ${ }^{106}$ There also exists the risk of implicit guarantees by stronger countries participating in the scheme as they would not want to let it break down. The determination of the yield to be paid may also be problematic because the national bond markets may be distorted when Eurobonds are introduced. ${ }^{107}$ Finally, in this scheme payments would be linked to the interest rates on national bonds. However, interest rates are not ideal proxies for credit risk and may therefore over- or understate the risk. ${ }^{108}$ The resulting uncertainty over the real risk of the bonds might reduce its attractiveness in the eyes of investors. Moreover, in the author's opinion the fact that countries will still pay the same interest rate as on their national bond would not contribute to eliminating the significant interest rate spreads in the Eurozone. Thus, budget financing will still remain

\footnotetext{
${ }^{104}$ Sylvester Eijffinger, 'Eurobonds - Concepts and Implications' in D Kolassa (ed.) Eurobonds - Concepts and Implications: Compilation of Notes for the Monetary Dialogue of March 2011 (European Parliament 2011)

$<$ http:/www.europarl.europa.eu/activities/committees/studies.do?language=EN $>$ accessed on 28 July 2012, 10.

${ }^{105}$ De Grauwe and Moesen (n 102) 4.

${ }^{106}$ Favero and Missale (n 23) 103.

${ }^{107}$ Eijffinger (n 104) 10.

${ }^{108}$ Favero and Missale (n 23) 106.
} 
relatively expensive which would certainly not speed economic recovery. One way would be to use the current reduced interest rates, but they were envisaged as a short-term solution on Greece's current debt. Furthermore, offering continued market access for states with high credit risk and interest rates is somewhat self-defeating. The scheme does not set any debt ceiling in terms of permissible lending. Thus, it does not provide any incentive for states to consolidate their finances. Markets may punish unsustainable budgets with higher interest rates but these disciplinary measures will be somewhat futile if the countries in question enjoy continued access to new funding, thereby circumventing the punishment of higher interest rates.

\section{EMU Fund}

Boonstra proposes to move from national to central financing for all public debt, thereby abolishing the possibility for countries to separately raise debt on financial markets. A newly created and independent EMU fund would be in charge of issuing Eurobonds. ${ }^{109}$ The common bonds would be backed by several and joint guarantees where each participating issuer would guarantee the totality of the obligations of the common instrument. In this scheme, the countries with the best credit ratings, namely Germany and France, would serve as a basis for the overall credit standing of the common government bond. Their participation would ensure a lower credit risk premium than the weighted average of the participating countries even if some of them had lower credit standings. ${ }^{110}$ The EMU fund would finance itself by issuing bonds in the markets and the proceeds would be issued to the participating countries. The latter would be charged a fee that includes their funding costs plus a margin. This margin would be based on the deficit and public debt of the respective country, as measured against the deficit and debt deviations from the average levels of Germany and France. Since the latter provide the benchmark against which all other countries are judged, neither of

\footnotetext{
${ }^{109}$ Wim Boonstra, 'Central funding of public deficits, combined with a renewed Stability and Growth Pact, can stabilize the eurozone' (2011) 2011 Rabobank Working Paper Series No. 02

$<$ www.rabobank.com/content/images/WP1102wbo\%20central\%20funding\%20EMU \%20fund_tcm43-134863.pdf $>$ accessed on 2 August 2012, 7.

${ }^{110}$ Favero and Missale (n 23) 99.
} 
them would have to pay a margin. If a country performs better than France and Germany, it would be absolved from paying the margin. ${ }^{11}$ Thus, there is a strong incentive for countries to improve their fiscal deficits. On the other hand, countries that run excessive deficits will be subject to punishment. Overall, fiscal stability would be improved, thereby strengthening the EMU fiscal framework. The several and joint guarantees of the participating states are a potential violation of the nobailout clause. However, this concern is addressed by the funds amassed through the premium payments. Consequently, in the unlikely event of a country defaulting, these funds would act as a buffer.

Nonetheless, this scheme also faces potential problems. In particular the setting of the parameters and the base rate for the premia may be problematic. Mayordomo proposes a compensation scheme based on the indexation of the interests paid by the participants. Consequently, each country would pay on its share of the Eurobond a margin equal to the credit risk premium, as measured by CDS, on its national bonds while the remaining interest payments would be proportional to the share of the Eurobond. ${ }^{12}$ However, while risk premium measured by CDS may provide an accurate assessment for bonds issued on national markets, this may not be the case for Eurobonds. Using CDS to assess a bond backed by the joint guarantees of several countries may potentially overstate the credit-risk contribution of the participants. ${ }^{113}$

Moreover, while arguably imposing fiscal discipline, the additional premium would not reduce the interest rate spreads within the EMU. Depending on the level of the premium, it might not even be beneficial for countries with weak budgets to join this scheme. The participation of France and Germany would indeed be crucial for the effectiveness of the scheme since they would guarantee a lower credit risk rating of a common bond. However, linking the premium to their fiscal policies would not necessarily guarantee fiscal prudence. Both countries have been known to disregard the SGP. In fact, when they first exceeded the $3 \%$ deficit limit, they tried to escape both the early warning and the excessive deficit procedure. They avoided a fine and even succeeded in

\footnotetext{
111 Boonstra (n 109) 7.

112 Mayordomo, Peña and Schwartz (n 88) 18.

${ }^{113}$ Favero and Missale (n 23) 106.
} 
changing the rules of the SGP in their favour. ${ }^{114}$ With this history, the question arises whether they would pay have to pay higher premia once they exceed a certain limit and if they would be willing to do so. Thus, there may be the risk that they would exert political pressure to keep their premium-free status, which would undermine the whole purpose of the scheme.

\section{Blue and Red Debt}

Delpla proposes to divide debt into senior (Blue) and junior (Red) debt. ${ }^{115}$ The proposal states that countries should pool their debt to the Maastricht limit of a maximum of $60 \%$ of GDP in senior blue bonds. Beyond the $60 \%$ level, they would have to go to the capital market on their own, which would lead to higher borrowing costs. This part of the debt would be the junior debt in the form of red bonds. Sovereign debt would be tranched so that the senior blue bonds would have greater liquidity and a lower risk of default. The junior red bonds, on the other hand, would be less liquid and carry the same default risk as before. Since red bonds would be subject to higher interest rates, countries would have an incentive to consolidate their budget to bring their debt to below $60 \%$ of GDP. The task of allocation of risk would fall to an independent committee, which would analyse the debt path and fiscal policies of the participating countries. On this basis, the committee would outline the prudent allocation of senior debt for each country over the next fiscal year. $^{116}$

The advantages of this scheme include the elimination of interest rate spreads for blue debt. This would lead to improved liquidity of a large part of government debt, resulting in lower borrowing costs. Moreover, this scheme could serve as commitment device for countries with weak fiscal policies to improve their budgetary balance. Imposing a ceiling of $60 \%$ of GDP on the blue bond quota effectively links the scheme to fiscal discipline, thereby strengthening the credibility of the SGP. ${ }^{117}$ However, the fact that the debt is guaranteed severally and jointly

\footnotetext{
${ }^{114}$ Kösters (n 21) 136.

115 Jacques Depla, 'Blue bonds: creating a pan-European common government debt' (2010) 14 Cahier Comte Boel 15.

116 ibid 17.

${ }^{117}$ Eijffinger (n 104) 10.
} 
by the participating members also presents a potential infringement of the no-bailout clause. The risk of default arising under scheme is very low as it promotes and rewards responsible borrowing. In the unlikely event that a country should default, an orderly bankruptcy procedure could provide an adequate safety mechanism. ${ }^{118}$ The author envisages that a new stability council should be established that would be responsible for the administration of the scheme. ${ }^{119}$ However, this would require the existing Treaty to be amended or a new Treaty to be signed, which would then also affect countries outside the Eurozone. Considering the trouble preceding the ratification of the Lisbon Treaty, amending an existing or signing an entirely new Treaty would very likely cause further problems.

The original proposal by Depla excludes Greece from participating in the scheme due to its history of falsifying data and lying about the true state of its public finances. ${ }^{120}$ While this is, in principle, a valid argument, excluding a country that would greatly benefit from cheaper financing to consolidate its finances would not be conducive to restoring the fiscal balance of the Eurozone. Using the example of Greece, the other question that arises is whether the scheme would be effective for countries whose senior debt levels exceed $60 \%$. This could be solved by adding grey bonds to the red and blue bonds scheme. Grey bonds would then represent old debt that precedes the start of the scheme. ${ }^{121}$ This debt would attract the same interest rates as before the start of the scheme. In the case of Greece, Ireland and Portugal, this would mean that they could still profit from the reduced interest rates that were agreed upon after the second bailout. In the meantime, they could pool the other $60 \%$ of their debt into blue bonds, which would guarantee greater liquidity, allowing them to consolidate their finances.

Moreover, the issue of outside borrowing is not addressed. Hence, to further strengthen the credibility of the scheme, it would be beneficial to include an agreement prohibiting participants to borrow 'on the side'. ${ }^{122}$ Finally, the transition from the current debt to the new system of red and blue bonds is somewhat problematic. Delpla proposes a phasing out of

\footnotetext{
118 ibid.

${ }^{119}$ Depla (n 115) 17.

120 ibid.

${ }^{121}$ ibid 19.

${ }^{122}$ Eijffinger (n 104) 10.
} 
national debt by letting blue and red bond issues replace national bonds. ${ }^{123}$ While there may be strong incentives for investors, the replacement itself is mandatory as a forcible exchange would be considered as default, that would could severe turmoil in the financial markets. ${ }^{124}$ However, such a voluntary replacement procedure is problematic. Some private investors may use the exchange scheme to their advantage by free-riding and refusing to replace their bonds. This would put additional pressure on other investors to buy them out. However, while not entirely eliminating the risk, collective action clauses could potentially reduce free-riding. The effectiveness of such clauses would depend on the stipulated threshold that, given a certain percentage of investors is present, would allow them to act on behalf of the whole group. To solve this problem, the new debt criteria could only be applied to fresh debt while holders of old debt could still exchange their bonds on a voluntary basis. ${ }^{125}$

\section{Eurobonds Issued by an EU Institution}

The final proposal is a common bond issued by an EU Institution. The respective institution would lend the funds raised with common bonds to EU members at an interest rate that reflects the funding costs. These bonds would be backed by the several and joint guarantees of the $27 \mathrm{EU}$ members. The guarantees would not be explicit but derive from the EU legal order. If, for example, the common bond were issued by the European Commission the guarantees would derive from the legal obligations under the EU Treaty. On the other hand, if the bonds were issued by the EIB, it would be backed by the capital subscribed by EU members. In both cases, the issued bonds would have a very low risk premium and benefit from high credit quality. ${ }^{126}$ The fact that such bonds would be practically riskless, since they have the backing of all EU member states, would make them extremely attractive for investors. Moreover, the risk of moral hazard would be reduced by distributing

\footnotetext{
${ }^{123}$ Depla (n 115) 18.

124 ibid 19.

125 ibid.

${ }^{126}$ Favero and Missale (n 23) 100.
} 
losses across EU members according to where they arose. ${ }^{127}$

The major limitation of this proposal is that it fails to take into account the diversity of the existing institutional arrangements that link the members of the EU. ${ }^{128}$ The EU Treaty concerns all 27 Members whereas, at the time of writing, the Eurozone features only 17 members. Thus, if a common EU Institution were to become the single issuer of such bonds, non-Eurozone countries would have to guarantee the debt of the Eurozone. ${ }^{129}$ This would very likely lead to strong political opposition, at worst resulting in further fragmentation of the EU. Moreover, merging under a single arrangement would be problematic because it would ignore the differences of institutional arrangements between the EU and the Eurozone. As a consequence, markets as well as investors could become very confused. They would not know whether EIB securities benefiting from a joint and several guarantee of its 27 shareholders would be superior to securities guaranteed by members of the Eurozone and vice versa. ${ }^{130}$

The fact the bonds would be guaranteed through the EU legal order and thus by its members presents a potential violation of the no-bailout clause. Bestowing upon an institution the power to raise funds for deficit financing would require a change in the present legal framework. However, as mentioned, going through the bureaucratic procedure of amending the existing Treaty could be very problematic. This could be circumvented by relying on Article 352 , which allows the Council to adopt actions necessary for the attainment of the Treaties' objectives. Another alternative would be to allow the European Commission to raise funds under Article 122(2). The scope of the latter is restricted to financial assistance by the Council in case of difficulties caused by exceptional circumstances. ${ }^{131}$

\footnotetext{
${ }^{127}$ Daniel Gros and Stefano Micossi, 'A bond-issuing EU stability fund could rescue Europe' (2009) 11 Europe's World 83, 86.

${ }^{128}$ Paul Goldschmidt, 'Reply to: A bond-issuing EU stability fund could rescue Europe' (2009) <www.astrid-online.it/Dossier--d1/EUROBONDS/Rassegnas/Goldschmidt_Europe-sWorld_2009.pdf > accessed on 16 August 2012, 3.

${ }^{129}$ Favero and Missale (n 23) 105.

${ }^{130}$ Goldschmidt (n 128) 3.

${ }^{131}$ Favero and Missale (n 23) 105.
} 


\section{Alternatives to Eurobonds}

One alternative could be common bonds issued by countries with the same credit ratings. This would not necessitate a Eurozone-wide guarantee scheme, which would reduce risk of free-riding and moral hazard. Countries with a triple-A rating such as Germany and France would not issue common bonds since they would not derive any significant benefits from doing so. A bond issued by a group of countries with a double-A-rating, on the other hand, may have greater liquidity. However, an alliance of states with a simple A-rating would be weak and thus fail to generate sufficient liquidity. The risk of bailout in this scheme is less pronounced but the question of whether there is a potential infringement of the no-bailout clause remains. ${ }^{132}$ Under this scheme, interest rate spreads would be eliminated within the group of the issuing countries but it would still be present within the Eurozone. Moreover, the common bonds under this scheme would have to compete with the more liquid bonds of triple-A-rated countries such as Germany. Investors would most likely prefer the latter's bonds. Thus, it is doubtful whether there would be a prominent increase in liquidity, sufficient to act as an incentive for countries to join the scheme.

Another alternative would be a common bond issued by both small and medium-sized countries. ${ }^{133}$ This would involve the participation of states with different ratings while Germany and France would be excluded from the scheme. The design of such a bond would be similar to the joint bond issued by German federal states. Despite having low borrowing needs, they had to invest or raise funds in the money market between their issuing dates. Hence, some federal states issued joint Jumbo bonds to avoid additional liquidity management costs. Investors benefited from higher liquidity as well as risk-free assets since the bonds were jointly and severally guaranteed by the issuing federal states. On a European level, common bonds issued by small and medium-sized EMU countries would provide for greater flexibility in terms of coordinating issuing activities. Becker states that countries should only cooperate in issuing common bond with the EMU members that 'have a good track

\footnotetext{
${ }^{132}$ Becker (n 8) 30.

133 ibid.
} 
record of fiscal policy'. ${ }^{134}$ Thus, countries would have an incentive to pursue sound fiscal policies in order to be invited to participate in a common bond. ${ }^{135}$ However, considering the financial track record of countries in the Eurozone, this would leave relatively few parties that would qualify for the scheme. Moreover, like the previous proposal, this scheme is marred by a potential lack of liquidity as a result of the wide interest rate differentials in the Eurozone. In a competition with French and German bonds, even with the common guarantees of all other EMU members, the latter stand to lose.

\section{H. Proposal for an EFfective ENForcement of EURobonds}

In the author's opinion, Depla's proposal is best suited to strengthen the fiscal framework of the EMU and enforce discipline in the Eurozone, but some amendments need to be made to make it effective. In order to create a thick market, Eurobonds would have to be sufficiently large, regular and predictable. Thus, they would have to be based on an issuing calendar that specifies the minimum amounts to be offered. ${ }^{136}$ Moreover, there are situations that have an impact on the entire Eurozone, thereby potentially affecting the credit quality of the bonds. Since Eurobonds provide increased liquidity, this may result in higher capital inflows and an increased exchange rate of the euro. The ECB would have to counteract these increases. Consequently, it would be advisable for countries to issue Eurobonds alongside a supranational institution that would be able to account for all these factors and coordinate the bond issues. Creating a new institution would just add an unnecessary layer to the European bureaucracy and thus an existing institution should assume the task. Given its intended role of stabilising the EMU, the EFSF and its successor the ESM would be the best solution. In order to account for the potential factors affecting the EMU and thus the bond issues, the scope of the EFSF (and ESM) should be broadened to provide for greater coordination with representatives of the European Commission and the ECB. ${ }^{137}$ It would also be advisable to introduce a requirement that, in addition to their annual stability programmes, countries participating in

\footnotetext{
134 ibid 31.

135 ibid.

${ }^{136}$ Favero and Missale (n 23) 116.

${ }^{137}$ Panico and Suarez (n 51) 26.
} 
the issue of Eurobonds would have to provide estimates of off-budget liabilities, net asset positions and long-term budgetary trends to an expert committee. ${ }^{138}$ Eijffinger's proposal of a Fiscal Experts Panel (FEP) would be applicable in such a framework, albeit in a slightly different form. Under the auspices of the EFSF (ESM), the FEP would analyse each country's deficits and debt levels as well as fiscal policy and monetary trends. Based on these factors, the FEP would then determine a corresponding allocation of Eurobonds to be issued.

In order to avoid free-riding and moral hazard, the FEP would impose specific limits on the volume of bonds a country can issue annually. Countries would not be allowed to issue Eurobonds exceeding $60 \%$ of their GDP. Moreover, it would be prohibited to authorise a net increase in their total Eurobond responsibilities that would amount more than $3 \%$ of their annual GDP. Consequently, Eurobonds would only be available for funding sustainable debt. Debt amounting to more than $60 \%$ of GDP would have to be financed through national government bonds. As they are subject to the financial markets, they would attract a different rating and thus a higher interest rate compared to Eurobonds. This would provide clear incentives not to engage in excessive borrowing because the costs would be considerably higher. ${ }^{139}$ Under this system, there would be clear rewards for enforcing fiscal discipline in the form of cheaper budget financing and clear penalties for failing to do so through higher prices.

Boonstra would criticise that 'countries still are vulnerable for swings in market sentiment'. ${ }^{140}$ However, this would only be true for excessive debt. In fact there are strong incentives for countries to reduce their deficits and run prudent fiscal policies. Although the risk of default under this scheme is very low, the classic conflict with the no-bailout clause remains. This could be solved by introducing an adequate insolvency mechanism. After Greece's debt restructuring which featured a $€ 206$ billion bond exchange and is now considered the 'biggest sovereign default in history' ${ }^{141}$ sovereign insolvency is no longer anathema. In fact, as of 1 January 2013, CACs will be included in all new euro area

\footnotetext{
${ }^{138}$ Buti, Eijffinger and Franco (n 38) 26.

${ }^{139}$ Erik Jones, 'A Eurobond Proposal to Promote Stability and Liquidity while

Preventing Moral Hazard' (2010) 180 ISPI Policy Brief, 2.

${ }^{140}$ Boonstra (n 109) 6.

141 'The wait is over' The Economist (London, 17 March 2012), 67.
} 
government securities with maturity above one year. ${ }^{142}$ Thus, under an insolvency mechanism, negotiations with private bondholders could be conducted swiftly, allowing a country to restructure its debt in an orderly manner, thus preventing panic in the financial markets. In order to avoid an arduous and lengthy amendment process at the EU level, such a sovereign insolvency mechanism could be created by way of an intergovernmental agreement between the members of the Eurozone.

The other problem is the fact that countries with high credit ratings and low interest rates such a Germany may face higher costs through Eurobonds. The pertinent issue is whether they would agree to dilute their credit rating by issuing joint bonds with countries with weaker ratings. ${ }^{143}$ The German finance minister suggested that Germany could face extra annual funding costs of up to $€ 3 \mathrm{bn} .{ }^{144}$ While, at the time of writing, Germany vehemently opposes the introduction of Eurobonds, it may actually benefit from them. German banks would consider them a very attractive and safe investment. Many more banks would likely follow suit. The resulting stabilisation of the European banking sector and the stabilisation of the European periphery would further boost the German export sector. ${ }^{145}$ Moreover, given the weak status of the Dollar, Eurobonds with extreme liquidity and low credit risk could rival American's treasuries market for liquidity, supplanting the status of the Dollar as reserve currency. ${ }^{146}$ The higher interest rates would be a trade off for economic stability. In any case, these would be minor costs compared to Germany's participation in the recent bailout packages. As an example, Germany contributes $€ 22$ billion to the paid-in capital of the ESM while also securing guarantees of up to $€ 168$ billion. Moreover, the higher costs may just be temporary since increased attractiveness to investors is likely to enhance the credit rating of Eurobonds, which would over time decrease interest rates.

\footnotetext{
142 Treaty establishing the European Stability Mechanism, Article 12 (3).

143 Thomas Mayer, 'Market view', in Jean Pisani-Ferry and Adam S. Posen (eds), The Euro At Ten: The Next Global Currency (The Peterson Institute for International Economics 2009), 178.

${ }^{144}$ Wolfgang Münchau, 'The Benefits of a Single European Bond' Financial Times (London, 25 January 2009) <http://www.ft.com/intl/cms/s/0/77da5df0-eae5-11ddbb6e-0000779fd2ac.html\#axzzlumCU7Qkt> accessed on 13 August 2012.

${ }^{145}$ Gros and Micossi (n 127) 86.

${ }^{146}$ Mayordomo, Peña and Schwartz (n 88) 2.
} 


\section{CONCLuSion}

In conclusion, the proposed introduction of Eurobonds would significantly strengthen the fiscal policy framework of the EMU. They would provide short-flexibility since access to financial markets and high levels of liquidity would allow countries to respond to shocks. And the incentive of cheap budgetary funding would enforce fiscal discipline while also ensuring economic recovery and long-term sustainable debt levels in the Eurozone. A further step forward would now be the establishment of a European Monetary Fund (EMF) as a platform to coordinate national fiscal policies and monetary policy. It could also coordinate the issue of Eurobonds and provide funding to countries facing financial difficulties. ${ }^{147}$ In the author's opinion this would be a desirable development but, given the current turmoil, would come too early. It would therefore be advisable to wait with the creation of a European Monetary Fund until the Eurobonds system has proven successful and deficits in the Eurozone have returned to relatively sustainable levels. If the system is effective, this will serve as an automatic incentive to enter discussions about extending Eurobonds to the EU as a whole. Establishing a European Monetary Fund would then be a major move in the direction of a political union. However, these developments should not be rushed. Nonetheless, Eurobonds would be an important first step towards further political integration.

${ }^{147}$ Thomas Mayer, 'The Case for a European Monetary Fund' (2009) 44 Intereconomics 140. 